\title{
Rice Husk Gasifier Experiment as Biofuel Source in UiTM Pulau Pinang
}

\author{
M.M. Mahadzir* ${ }^{1,2}$, M.D. Zikri ${ }^{1}$ and N.I. Ismail ${ }^{2}$ \\ ${ }^{1}$ Faculty of Mechanical Engineering, Universiti Teknologi MARA Pulau Pinang, Jalan Permatang \\ Pauh, 13500 Bukit Mertajam, Pulau Pinang, Malaysia. \\ ${ }^{2}$ Automotive Research and Testing Center (ARTeC), Universiti Teknologi MARA Pulau \\ Pinang,Jalan Permatang Pauh, 13500 Bukit Mertajam, Pulau Pinang, Malaysia.
}

\begin{abstract}
Rice husk gasification developed as process that converts organic rice husk into a producer gas. The achievement is to reduce dependency on fossil fuel, reduce pollution and move into green technology. Downdraft gasifier is a reactor that can produce lower tar concentration in the producer gas. There are important objectives had been investigated which are to modify on laboratory scaled downdraft gasifier from the previous project, where suitable with the rice husk gasification system, to measure the exit temperatures in gasifier which it determine tar quantity at the output, to measure the amount of moisture removed from the rice husk where it determine the quantity of moisture in rice husk and, to measure the complete burning of rice husk in a gasifier by taking the time performing the experiments. All the objectives are to be obtaining the output which can be used as a biofuel sources. The method to achieve the objectives, firstly redesign performed using SolidWork software. Next, the temperature determined using thermocouple. Then, next objective which the rice husk drying analysis determined by drying rice husk and scale it with weighing scale. And lastly, burning was determined by using stopwatch and weighing scale with complete fabricated gasifier. The results shows the fabrication of the modification, average exits temperature of producer gas which around $203.93^{\circ} \mathrm{C}$, different moisture weight of rice husk which around 10grams and, average time of completes burning of gasifier is 61 minutes and ability to capture producer gas's flammability. This work concluded by achieves the objectives based on the results and may increase in understanding of the works related.
\end{abstract}

Key words: gasifier, rice husk, biofuel

\section{INTRODUCTION}

Biomass energy is derived from five distinct energy sources which are garbage (Solid waste), wood and agricultural products, waste, landfill gases, and alcohol fuels [1]. Rice husk is one of the biomass sources where the materials are readily available in large quantities but easy to collect. The choice of the energy is due to demand of energy in industries and households which are extremely high. Renewable energy is the right alternative energy source that can be substituted for fossil fuels.

Current environmental problems have different causes including global warming due to emissions of greenhouse gases (GHGs) which are generated mainly from the combustion of fossil fuels such as diesel, gasoline or coal [2]. In order to face future problems, there are policies that the government had proposed. In this sectors, all the research studies is aimed to obtain energy from various biomass including agricultural solid residues, such as coffee husks, rice husks, sugar cane bagasse and wheat straw. Among all the others, rice husk is the one of that the very least used in developing countries. Biomass is a promising and renewable energy source that is estimated to contribute $10 \%$ to $14 \%$ of the world's energy supply [3].

Rice husk (or rice hull) is the hard protecting cover of grain of rice which it is indigestible to humans. Its main function is to protect the seed during growing season. It produces consistent amounts annually which possibly able to secure a raw material supply [4]. Based on the statistic, the amount of rice produced by world annually is more than 120 million tons. This shows that we are able to be a new potential bio-energy production in Malaysia. Following the report from USDA Foreign Agricultural Service (2017), the forecast of rice production in Malaysia is at 1.8 million tons in 2016/17 and increasing 0.02 million tons in 2017/18. It is a major

Corresponding Author: M.M.Mahadzir, Faculty of Mechanical Engineering, Universiti Teknologi MARA Pulau Pinang, Jalan Permatang Pauh, 13500 Bukit Mertajam, Pulau Pinang, Malaysia, email:mahadzir399@ @pinang.uitm.edu.my. 
by-product of the rice-milling industries and is abundantly available. South and Southeast Asia account for over $90 \%$ of the world's rice production [5]. However, rice husks have been considered a waste, causing disposal problems. Asia itself produces the vast majority of global rice at around 770 million tons annually. Around $20 \%$ of the rice weight can be attributed to the husk or hull which is not consumed and often disposed of. This equates to 150 million tons of biomass fuel annually.

Gasification is thermo-chemical process of converting carbonaceous materials into gaseous products using a gasifier with a gasifying medium such as air, oxygen and steam either alone or in mixture [6]. The producer gas as the output could be used as a fuel in engines for power generation; thus, it is a promising technology to provide electricity in remote districts by using local, renewable fuels [3]. Producer gas is a product of gasification, exits the gasifiers through gas outlet at the lower part of the gasifiers. Typically, producer gas is a mixture of combustible gas such as $\mathrm{CO}$, $\mathrm{H} 2$, and $\mathrm{CH} 4$ and non-combustible gas such as $\mathrm{CO} 2$ and N2 [7]. Producer gas has a lower heating value than the other gaseous fuels, but it can be manufactured with relatively simple equipment; it is used mainly as a fuel in most large industrial furnaces. Downdraft gasifier is one of the types of gasifier system and is the most suitable gasifier system in order to perform in lab-scaled gasifier. Downdraft gasifier is easy in fabrication and operation and attractive due to low tar content in producer gas. The gasifier has a sequence in the reactor itself. It is unrealistic to split gasifier into multiple zone, but to understand and differentiate the zones, separation of the process is involves. Those zones are drying, pyrolysis, partial oxidation and reduction zone.

In this work, the problem defined based on the previous work design in [8]. There was a change and modification need to be performed as it has to be suitable with the material use which is rice husk. Thus, the modification design was approach as the objectives on this work which to be a deep understanding of the process of energy production by the downdraft gasifier on of method to obtained biofuel sources.

\section{METHODOLOGY Research Activities}

The project starts with literature review, feasibilities studies, design making, fabrication and experimental. The biomass material which is rice husk was recieved from Kompleks Syarikat Padi Beras Nasional Berhad (BERNAS) Megat Dewa at Wang Perah village, Ayer Hitam district, Kedah, Malaysia. Design and drawing had done by using SolidWorks software. In order to improve the performance of downdraft gasifiers, the basic design of the gasifiers is modified. Below show the gasifier before modification work.

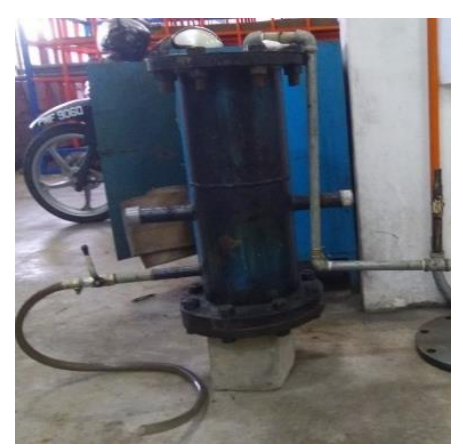

Figure 1: Gasifier before modification

\section{Experimental Set-up}

Various improvements on the basic design of the gasifiers have been done and reported by many researchers. The modification contributes in replacing top pipe of gas outlet to the hopper. While the output of producer gas release at the bottom area of gasifier. The fabrication of modified gasifier contributes material of Galvanized Iron (GI) steel pipe that place on the hopper to connect with the gasifier. Use of reducer pipe and male socket in this process will help transferring the rice husk in the hopper. And the sheet metal which shaped was done for the hopper funnel. Below shows the planned of setup experiment for gasifier which used to obtain the result of experiments.

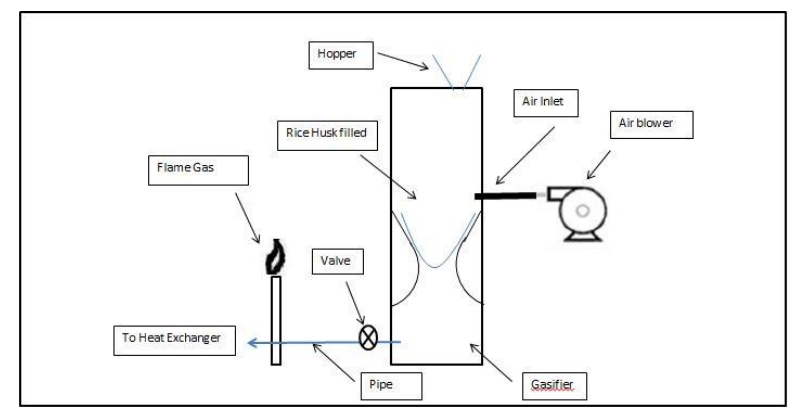

Figure 2: Experiment Set-Up

Downdraft gasifier was made in lab-scaled that made in mild steel and it has designed and fabricated with 1kilogramm capacity of rice husk. Material use is rice husk as a biomass and the rice husk is set to full the whole reactor. To fill in the reactor, the rice husk was weighed using weighing scale before being filled into the reactor and left for burning in full capacity. As an ignition method, the husk being a diesel on the materials and use the burning materials (starter burner) to help the burning process. 
Air was supplied from with the air blower in order to have perfect combustion. A gasifier gas was obtained after more than an hour work. Gases produced from the reactor will release through the bottom section. Then, a thermocouple was installed near the gas outlet to monitor temperature of the exit gas. In addition from all the work, the full capacity of rice husk in reactor will be recorded for the work to estimate the time to complete full capacity burning of gasifier. In addition, the entire rice husk was dried before performing the experiment which to measure amount of moisture removed from the rice husk in the gasifier.

Temperature reading has taken for every experiments run. For the full capacity time estimation, time taken had started from the burning process until all the systems stops. Drying the rice husk done by placed the rice husk under the sun. However, to obtain the strong results, the experiment was done in multiple times including considering temperature of surrounding (ambient temperature), climate and weather was at the right and suitable to run the experiment.

To achieve all the results required, equipment of all the experimental methods has to be determined. In every run, the gasifier was cleaned after the process had finished removing the unburned husk, tar and ashes inside the reactor. Adjustable spanner was used to loosen the entire nut and bolt around the lid and tighten it all back after cleaning process was completed.

There are the must to make an experiment procedure of gasifier. At the early process, all parts of reactor were properly tightened. Place the reactor at the open space for the testing process. Then, fill up a few of the rice husk into the throat as a starting process. Use starter burner to burn the rice husk. When the combustion was stable, the remaining of the rice husk fed into the reactor at the maximum or full scale. The mass of rice husk filled in the reactor were measured and set the stopwatch to evaluate the time taken to complete burning all rice husks. The use air blower was to supply sufficient air due to assist the combustion. Thermocouple placed at the end where producer gas is visible. Output temperature of producer gas was taken in every experiment. Then, the gas produce will be recorded and use as the biofuel in the engine. Finally, all the results are recorded.

The experiment has run for three results to obtain the average result. Modification had taken part in order to have better gasifier system in performing the experiment. After every run of gasifier, the unburned rice husk, tar and ashes in the gasifier will be cleaned as part of maintenance purpose. New rice husk used for the new experiment.

\section{RESULT AND DISCUSSION \\ Fabrication and Design Result}

Full gasifier system has already fabricated based on [8]. In the design, modification was taken as the parts to be design and drawing of the hopper was done as modification parts. In general, downdraft gasifier's internal diameter was $304.8 \mathrm{~mm}$ and outer diameter was $324.8 \mathrm{~mm}$. Reduction zone height was $50 \mathrm{~mm}$ and diameter of $100 \mathrm{~mm}$. Others, combustion zone has height of $40 \mathrm{~mm}$ and diameter of $80 \mathrm{~mm}$. Air inlet and gas outlet had diameter of $30 \mathrm{~mm}$ and $20 \mathrm{~mm}$ respectively.

Focus on the design of modification, there were two (2) parts that contributes; first was a hopper funnel, and second was a top lid of gasifier. Both parts located at the top of gasifier system. For the hopper funnel, the top thickness for hopper was $2 \mathrm{~mm}$ and the top or inlet diameter of hopper was $160 \mathrm{~mm}$ along $40 \mathrm{~mm}$ height. Choke area decreasing diameter from $160 \mathrm{~mm}$ to 34.1 $\mathrm{mm}$ for $60 \mathrm{~mm}$ height. Bottom area of hopper had 34.1 $\mathrm{mm}$ for the inner diameter and $38.1 \mathrm{~mm}$ for the outer diameter along $101.6 \mathrm{~mm}$ height. For the top lid of gasifier, the adjustment had made in order to place the hopper at the upper lid of gasifier. The upper lid diameter was $404.8 \mathrm{~mm}$ and consists of small hole around the upper lid that used to close the gasifier with the bolt and nut. The small hole was $10 \mathrm{~mm}$ sized. In order to meet with the hopper size and connect with the lid, the hole had been made with the diameter of 38.1 $\mathrm{mm}$ on the top of gasifier. To have better connection between hopper and upper lid, the reducer and socket had been place to joint both parts. It

connected with the socket and attached with the bottom side of upper lid. Overall, this gasifier had been reduced of it size in order to reduce some low temperature zone that appear in the throat zone that will result in a rise of tar content in producer gas. Drawings of each part are shown. Isometric, top and side view of gasifier shown below.
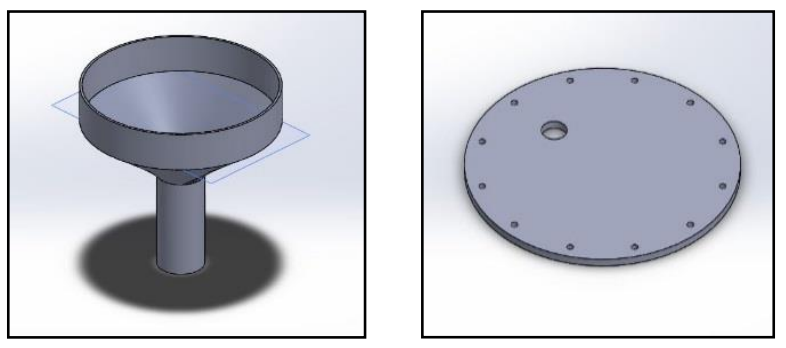

Figure 3: Isometric view of design for modification 


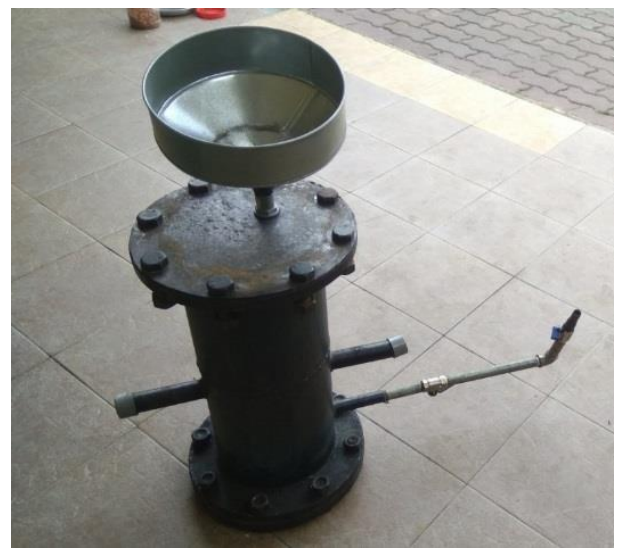

Figure 4: Fabricated design after modification

\section{Drying Analysis of Rice Husk}

The objective for this work is to obtain the amount of moisture in the rice husk. The experiment run in three consecutive days and set the measurement for every 2 hours. This work needs 10-hours to complete the work. Ambient temperature for every 2 hours had been taken provided by AccuWeather, which it used to seen the effect of the temperature with the moisture removal. In Table 1, it shows all the results of the experiment.

\begin{tabular}{|c|c|c|c|c|c|c|}
\hline & \multicolumn{7}{|c|}{ Weight (g) } \\
\hline TIME & $\begin{array}{c}7.00 \\
\text { am }\end{array}$ & $\begin{array}{c}9.00 \\
\text { am }\end{array}$ & $\begin{array}{c}11.00 \\
\text { am }\end{array}$ & $\begin{array}{c}1.00 \\
p m\end{array}$ & $\begin{array}{c}3.00 \\
p m\end{array}$ & $\begin{array}{c}5.00 \\
p m\end{array}$ \\
\hline $\begin{array}{c}\text { Day 1 } \\
(1 / 12)\end{array}$ & 100 & 100 & 97.5 & 94.0 & 91.0 & 90.0 \\
\hline $\begin{array}{c}\text { Day 2 } \\
(2 / 12)\end{array}$ & 100 & 100 & 98.0 & 95.0 & 93.0 & 93.0 \\
\hline $\begin{array}{c}\text { Day 3 } \\
(3 / 12)\end{array}$ & 100 & 98.5 & 97.5 & 94.5 & 92.0 & 91.0 \\
\hline & \multicolumn{7}{|c|}{ Temperature $\left({ }^{\circ} \mathbf{C}\right)$} \\
\hline TIME & $\begin{array}{c}7.00 \\
\text { am }\end{array}$ & $\begin{array}{c}7.00 \\
\text { am }\end{array}$ & $\begin{array}{c}7.00 \\
\text { am }\end{array}$ & $\begin{array}{c}7.00 \\
\text { am }\end{array}$ & $\begin{array}{c}7.00 \\
\text { am }\end{array}$ & $\begin{array}{c}7.00 \\
\text { am }\end{array}$ \\
\hline $\begin{array}{l}\text { Day 1 } \\
(1 / 12)\end{array}$ & 26 & 26 & 26 & 26 & 26 & 26 \\
\hline $\begin{array}{c}\text { Day 2 } \\
(2 / 12)\end{array}$ & 26.5 & 26.5 & 26.5 & 26.5 & 26.5 & 26.5 \\
\hline $\begin{array}{l}\text { Day 3 } \\
(3 / 12)\end{array}$ & 26.5 & 26.5 & 26.5 & 26.5 & 26.5 & 26.5 \\
\hline
\end{tabular}

By applying this drying process, we could understand that the good time to dry the rice husk will be taken after $9 \mathrm{am}$. The effect also determine from the daily temperature. Good results occur the drying when the temperature of that day was high. Therefore, with the decreasing number of weight, proved that the content of moisture in the rice husk contributes was around 10 grams. With the dried rice husk, we would be able to burn the rice husk perfectly. This should be a part of process when it came to the gasifying the rice husk. The primary result is the amount of moisture in rice obtained in this work was about maximum 10grams. The graph in Figure 5 shows the mass of rice husk before and after it dried. The graph in figure 6 shows the weight of rice husk and its effect with ambient temperature.

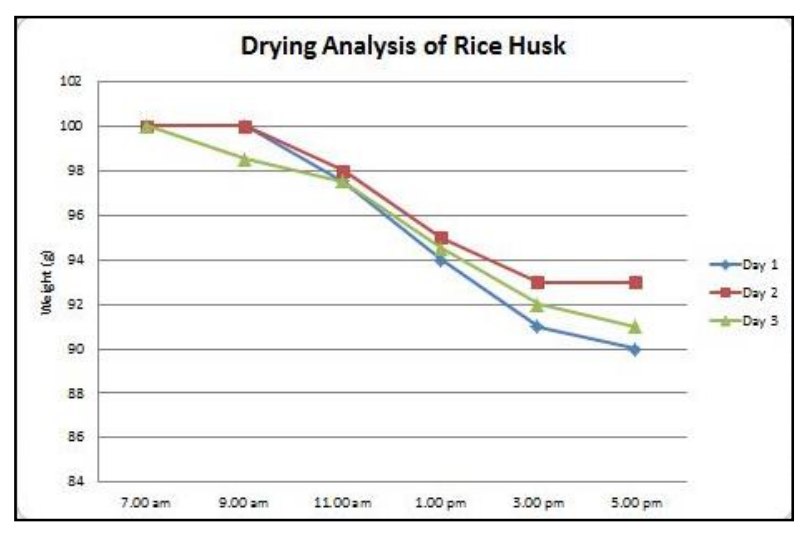

Figure 5: Drying analysis of Rice Husk 


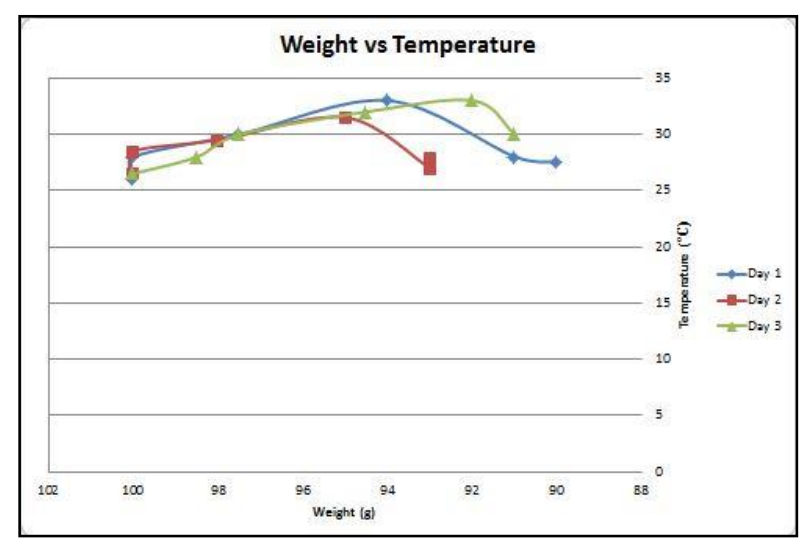

Figure 6: Weights versus Temperature

\section{Exit Gas Temperature \& Burning time of full lab- scaled gasifier}

The objective for this work is to obtain the exit gas temperature and time taken to complete burning of rice husk in a gasifier. Following the studies in [7], the writers said that the tar reduction process occurs inside the gasifier during gasification process. To obtain the temperature value, the thermocouple placed in the end of the gasifier system (output gas) whiles the value of time taken was able to measure from the stopwatch. Table 2 shows the temperature and time taken results from the experiment.

Table 2: Temperature reading for opening valve $\&$ Time reading for complete burning of Rice Husk

\begin{tabular}{|c|c|c|}
\hline Reading & Temperature $\left({ }^{\circ} \mathbf{C}\right)$ & Time $(\mathbf{m i n})$ \\
\hline 1 & 202.4 & $78 \mathrm{~min}$ \\
\hline 2 & 208.5 & $51 \mathrm{~min}$ \\
\hline 3 & 200.9 & 54 min \\
\hline Average & $\mathbf{2 0 3 . 9 3}$ & 61 minutes \\
\hline
\end{tabular}

By performing the experiment, we can see the temperature was around $203.93^{\circ} \mathrm{C}$ and it was lesser then theoretical stated by [9] which supposed around 300$400^{\circ} \mathrm{C}$. Meanwhile, the time taken for this work reaches the average time where 61 minutes was. It is because the gasifier able to withstand only $1 \mathrm{~kg}$ of rice husk, thus there need to be refilling process to extend the time for more. With the time experiment on the gasifier system here, we could be able to measure the capacity with the time taken produce on the work. The result of experiment in Table 2 was expressed in the graph on Figure 7 which shows the trend of the work.
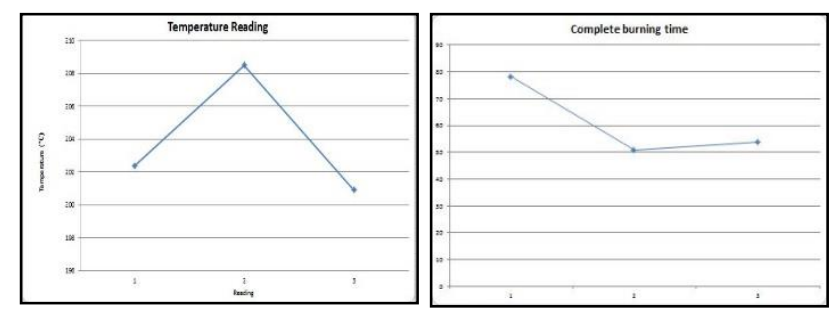

Figure 7: Reading of temperature at exit opening valve (left) and time for the whole complete burning (right)

\section{CONCLUSION}

A study of the downdraft gasifier has done on several years and current works on rice husk had taken part. The design of downdraft gasifier had been done and modification had taking parts so it was able to run with the rice husk source. The design of modified gasifier was fabricated and tested. The parameters of all parts on the gasifier had been measured and the equipment need in the work had been identified. All the results then were obtained from the experiment works. The value of moisture for rice husk for every 100 grams is around 10 grams. Average temperature and time taken to complete burning were $203.93^{\circ} \mathrm{C}$ and 61 minutes respectively. Therefore, the objectives of the works achieved and then it will help to overcome the problems.

\section{REFERENCES}

[1] Pradhan, A., Ali, S. M., \& Dash, R. (2013). Biomass Gasification by the use of Rice Husk Gasifier. Special Issue of International Journal on Advanced Computer Theory and Engineering (IJACTE), 14-17.

[2] Quispe, I., Navia, R., \& Kahhat, R. (2017). Energy potential from rice husk through direct combustion and fast. Waste Management 59, 200-210.

[3] Ma, Z., Zhang, Y., Zhang, Q., Qu, Y., Zhou, J., \& Qin, H. (2012). Design and experimental investigation of a $190 \mathrm{kWe}$ biomass fixed bed gasification and polygeneration pilot plant using a double air stage downdraft approach. Energy 46, 140-147.

[4] Yoon, S. J., Son, Y.-I., Kim, Y.-K., \& Lee, J.-G. (2012). Gasification and power generation characteristics of rice husk and rice husk pellet. Renewable Energy 42, 163-167. 
[5] Lin, K. S., Wang, H. P., Lin, C.-J., \& Juch, C.-I. (1998). A process development for gasification of rice husk. Fuel Processing Technology 55, 185-192.

[6] Ma, Z., Ye, J., Zhang, Q., \& Zhao, C. (2015). Gasification of Rice Husk in a Downdraft Gasifier: The effect of Equivalent Ration on the Gasification Performance, Properties, and Utilization Analysis of Byproducts of Char and Tar. Gasification of rice husk, 2999-2902.
[7] Susastriawan, A., Saptoadi, H., \& Purnomo. (2017). Small-scale downdraft gasifiers for biomass gasification: A review. Renewable and Sustainable Energy Reviews, 989-1003.

[8] Mahadzir, M., Aida, H., \& Ismail, N. (2017, May). Studies and design downdraft gasification for teaching and learning in UiTM Penang branch. Proceedings of Mechanical Engineering Research Day 2017, 211-212. 